Lektorált tanulmányok

\title{
Családok fesztiválélménye - két családbarát fesztivál elemzése
}

\author{
Szerzők: Ásványi Katalin ${ }^{1}$ - Mitev Ariel ${ }^{2}$ - Jászberényi Melinda ${ }^{3}$ - Mert Mentes ${ }^{4}$
}

A fesztiválokat sok esetben a családbarát szabadidôs tevékenységek közé sorolják, ugyanakkor kifejezetten erre a célcsoportra vonatkozóan a korábbiakban még nem végeztek kutatást a fesztivállátogatások tekintetében. Tanulmányunkban bemutatjuk, hogy a szakirodalom alapján milyen dimenziói vannak az élménynek, és értelmezzük azt a fesztiválokra vonatkozóan. Primer kutatást végeztünk és azt vizsgáltuk, hogy ezek a dimenziók milyen mértékben jelennek meg két magyarországi családi fesztiválnál, illetve hatással vannak-e a fesztivál emlékezetességére. A kutatás alapján megállapitható, hogy mindkét fesztivál esetében a szórakozás élménye hat legerósebben az emlékezetességre.

Kulcsszavak: fesztivál, élmény, emlékezetesség, családi turizmus.

\section{Bevezetés}

A fesztiválturizmus a turizmus egyik dinamikusan fejlődő ágazata, melyet az bizonyít, hogy 2009. óta már az Európai Bizottság Eurobarometer felmérése is külön megnevezi a fesztivállátogatást, mint utazási motivációt, valamint a desztinációk szempontjából is egyre nagyobb vonzerôt jelentenek (IPK 2008). A fesztiválok és a turizmus kapcsolata rendkívül régre nyúlik vissza. Ezen események a XXI. századra az ünnepléskultúra egyik legmeghatározóbb formájává váltak (SZABÓ 2012). A helyi közösség javára létrehozott fesztiválok (ÁSVÁNYI-JÁSZBERÉNYI 2017) mellett az utóbbi években ugrásszerúen megnőtt azon fesztiválok száma, melyeket kifejezetten a turisták számára hoztak létre, így leltárt készíteni róluk majdhogynem lehetetlen lenne (SMITH 2009). Számos kutató vizsgálja a kérdést, hogy mit is nevezünk pontosan fesztiválnak, ám a közösen elfogadott definíció ez idáig még nem született meg (JASSZBERÉNYI et al. 2017). Az ünneplés minden tekintetben átjárja a fesztivált. GETZ (1997) a következókkel azonosítja a fogalmat: attrakció, imázs épító, statikus attrakciók animátora és a fejlődés katalizátora. A Magyar

\footnotetext{
${ }^{1}$ egyetemi docens, Budapesti Corvinus Egyetem,

katalin.asvanyi@uni-corvinus.hu

${ }^{2}$ egyetemi docens, Budapesti Corvinus Egyetem,

ariel.mitev@uni-corvinus.hu

${ }^{3}$ egyetemi docens, Budapesti Corvinus Egyetem,

melinda.jaszberenyi@gmail.com

${ }^{4}$ PhD-hallgató, Budapesti Corvinus Egyetem, mertmentes@gmail.com
}

Fesztivál Szövetség definíciója már több konkrétummal szolgál. "Fesztiválnak nevezhetố minden olyan - egy vagy több téma köré szerveződô, rendszeresen megrendezésre kerüló, egy vagy több helyszinen történó, meghirdetett programmal rendelkezó kulturális, múvészeti, gasztronómiai, sport vagy egyéb - eseménysorozat, amelynek célja, hogy közönsége részére kiemelten színvonalas, értékközvetítô, minőségi, ismereteket is bôvitó és egyben szórakoztató, szabadidôs közösségi élményt nyújtson." (INKEI 2010:11, MFSZ 2014).

A családok szabadidő eltöltésével foglalkozó tanulmányok szerint a családon belüli kapcsolat, különösen a családtagokkal közösen megélt pozití élmények, a legfontosabb motivációs tényezőt jelentik a családi szabadidós tevékenységek esetében (HALLMAN-BENBOW 2007). Ugyanakkor SCHANZEL és SMITH (2014) rávilágítanak arra az ellentmondásos helyzetre is, miszerint a családi szabadidős tevékenységek esetén nemcsak a "családi ido" " fontos tényezö, hanem a "saját idôre" is figyelmet kell fordítani. Hiszen a családdal közösen eltöltött idő esetében lényeges, hogy megerősítse a családi kötelékeket, és lehetóséget biztosítson a közös élményszerzésre, ugyanakkor a saját idő, a saját érdekek érvényesülése is fontos szempont a szabadidő eltöltésekor, hogy a szülók is ki tudjanak szakadni a mindennapokból, és egy időre megszabaduljanak a családi élet kötelezettségeitól.

FOUNTAIN és szerzőtársai (2015) az édesapák és édesanyák közötti utazási preferenciák különbségére is rávilágítanak. Ez alapján megállapítható, hogy az édesapák számára kevésbé fontos a saját idő, és mivel úgy érzik, a mindennapokban kevesebb idôt tudnak a családjukkal tölteni, számukra a kö- 
zös időtöltés felértékelődik a saját idővel szemben. Szintén eltérés tapasztalható abban, hogy az édesanyákhoz viszonyítva az édesapák sokkal inkább támogatják a tanulási lehetőségeket a szabadidő eltöltése során. Az eredmények arra engednek következtetni, hogy a családi szerepek fontos tényezői a családi élmények megélésének, az emlékezetes élménynek és a visszatérés lehetőségének, melyek lényeges elemét képezik saját kutatásunknak.

\section{Szakirodalmi áttekintés}

\subsection{AZ ÉLMÉNY ÉRTELMEZÉSE A FESZTIVÁLOKON KERESZTÜL}

Tanulmányunk szempontjából a turisták élményszerzése és turisztikai élményének definiálása elengedhetetlen. Az élmény értelmezése a turizmusban az iparág szolgáltatásaiból adódóan speciális, hiszen lényegi elemét képezi maga az élmény, mely valójában a turisztikai tevékenység vagy esemény értelmét jelenti (OTTO-RITCHIE 1996). Az élmény jelentősége és annak növekedése egyre inkább érezteti hatását a turizmus területén. Az élmény meghatározására KULCSÁR (2015) három megközelítést alkalmaz. Egyrészt értelmezhetjük a fogyasztó érzelmi, fizikai, spirituális és intellektuális észlelései mentén, vagyis hogy a fesztiválon milyen fizikai környezet veszi körül, milyen érzelmeket vált ki belóle az ottlét, és ez milyen módon hat az intellektuális észlelésére. Ha az elégedettség oldaláról közelítünk, akkor a fogyasztó élményét az utazás előtti és utáni hatások összessége határozza meg, vagyis a fesztivál élményét az odaérkezés és hazaérkezés körülményei is befolyásolni fogják. A harmadik megközelítésben az élmény maga az autentikusság, a valódi, megtapasztalt élmény, vagyis a fesztivál autentikussága határozza meg leginkább (KULCSÁR 2015).

A turisztika élmény fogalmának nincs egységesen elfogadott definíciója, melynek sokféleségét MICHALKÓ és RÁTZ (2005) is alátámasztja, miszerint legjellemzóbb típusai az izgalom, a tényleges vagy észlelt veszély, az új ismeretek és készségek szerzése, az esztétikum, az együttlét és társaság, az újdonság, valamint az egzotikum. ZÁTORI (2014) megfogalmazásában a turisztikai élmény személyes jellegú, folyamatosan előforduló, újra és újra átélt, melynek feltétele, hogy a turista hajlandó és képes legyen elmerülni az élményben.

A fesztiválok kontextusában szerzett élmény öszszetett jelenség, melyet szisztematikusan és átfogóan is érdemes elemezni, ennek ellenére kevés tanulmány született ebben a témában (GETZ 2007). $\mathrm{Az}$ alábbiakban több kutatást is bemutatunk, mely valamilyen módon feldolgozza a fesztiválélmény elemeit, melyhez először elengedhetetlen, hogy magukat a fesztiválélmény dimenziókat értelmezzük PINE és GILMORE (1998) alapmodellje alapján, MANTHIOU és szerzőtársai (2014) feldolgozásában. PINE és GILMORE (1998) élménygazdasági koncepciójának lényege, hogy rávilágítson azokra az élményelemekre, melyek versenyelőnyt jelenthetnek a piac számára, melyet négy összetevő mentén határozott meg: tanulás, szórakozás, esztétika és eszképizmus. A szerzők (PINE-GILMORE 1999) megállapították, hogy a szolgáltatóknak emlékezetes élmény szerzésére kell törekedniük, hiszen több korábbi kutatás is kimutatta, hogy a fogyasztók korábbi emlékei és élményei fontos motivációs tényezői a pozitív visszajelzéseknek és az újralátogatásnak (TUNG-RITCHIE 2011, MANTHIOU et al. 2014).

A fesztiválok tanulási élményét több szerző kutatta (például CROMPTON-McKAY 1997, LEE et al. 2004), mely alátámasztja, hogy a tanulási dimenzió a fesztivállátogatás egyik legfontosabb motiváló tényezôje (PRENTICE 2004). Egyre inkább növekszik a keresleti oldali igény az olyan típusú élményszerzésre, mellyel a látogatók a tudásukat és/vagy készségeiket javíthatják a fesztiválon való részvétellel akár fizikai, akár szellemi fejlődésük érdekében (RITCHIE et al. 2003).

A szórakozás élménye a fesztiválon azt jelenti, amikor a látogató passzívan figyeli mások tevékenységét és/vagy előadását, melynek jó példái a zenei koncertek. A szórakozási élmény fontosságát mutatja, hogy több korábbi kutatás foglalkozott ennek feltárásával. VAN ZYL és BOTHA (2003) a helyi lakosok motivációit vizsgálta az Aardkop Múvészeti Fesztiválon, ahol a szórakozás élményelemeit azonosította. COLE és CHANCELLOR (2009) három attribútumot vizsgált, melyek hatással lehetnek a fesztivállátogatók élményére: a programokat, a szolgáltatásokat és a szórakoztatás minőségét, melyek közül a szórakozás minósége volt a legnagyobb hatással az optimális élményre, a látogatók elégedettségére és a visszatérési szándékra.

Az eszképizmus élménye GETZ (2007) megfogalmazásában úgy értelmezhetô, hogy az egyének változást és új élményeket akarnak szerezni, melyet a mindennapokból és a mindennapi környezetükből való kiszakadás által tudnak leginkább elérni. Erre megoldást nyújthatnak a szórakoztató parkok és tematikus éttermek. MORGAN (2009) megfogalmazásában a sikeres fesztiválok egyik legfontosabb jellemzője, hogy időt és teret adnak a fesztiválozók számára, hogy kiszakadhassanak a hétköznapokból, és ezáltal különleges élményekben legyen részük. KIM és szerzôtársai (2002) 
Lektorált tanulmányok

rávilágítottak arra, hogy a mindennapi életból való menekülés az egyik leggyakrabban említett motivációs elem a fesztiválok meglátogatásakor. UYSAL és munkatársai (1993) egy kukorica fesztiválon végeztek kutatást, ahol szintén az eszképizmus élménye volt a legfőbb motivációs tényező a fesztivál meglátogatására.

Az esztétikai élmény PINE és GILMORE (1998) értelmezésében lehet a fizikai környezet, a teljes atmoszféra vagy maga a hangulat értékelése. A nemzetközi irodalomban a festivalscape kifejezést használják a fesztiválok esztétikai élményének értelmezésére, mely a fesztivál alatt tapasztalt általános légkört jelenti, beleértve a kényelem, a személyzet, az információ, a programok, a létesítmények, az ajándéktárgyak és élelmiszerek összességét, melyek nagyban befolyásolják a fesztiválozók érzelmeit, elégedettségét és lojalitását (LEE et al. 2008). PRENTICE és ANDERSEN (2003) magát a fesztiválhangulatot nevezi meg, mint elsődleges motivációs tényezôt. MEHMETOGLU és ENGEN (2012) is az esztétikát, mint pozitívan befolyásoló tényezôt azonosították.

\subsection{A FESZTIVÁLÉLMÉNY MEGJELENÉSE KORÁBBI KUTATÁSOKBAN}

Szabadidős turisztikai szolgáltatások esetén az élményelemek beépítésével nagyban növelhetố a fogyasztók elégedettsége, melynek bizonyítására AKYILDIZ és ARGAN (2010) a török Rock'n Coke Fesztivál élményeinek vizsgálatát választották. A szabadidős élményekre vonatkozó korábbi kérdőíves kutatásokat alapul véve egy 19 kérdésből álló felmérést készítettek, melyet 234 fó töltött ki. A kapott eredmények azt mutatták, hogy a szabadidós élmény úgy fogalmazható meg, mint egy négydimenziós konstrukció. A szabadidôs élményeket leginkább a társadalmi kapcsolatok befolyásolják, melyet az életstílus, az érzelmek kifejezése és az érzéki észlelés követ. A közösségen alapuló fesztiválok imázsát vizsgálták egy kutatásban, melyben annak négy elemét azonosították (attribútumok, család és barátságosság, affektív asszociáció, átfogó értékelés) és amelyben az is megjelenik, hogy a fesztivál mennyire ideális a családi együttlét, a közös idótöltés számára (HUANG et al. 2010).

MANTHIOU és szerzőtársai (2014) az élménygazdasági koncepciót alapul véve, PINE és GILMORE (1998) modellje alapján négy dimenzió mentén vizsgálták a fesztivállátogatók élményeit, illetve azok hatását az emlékezetességre és a húségre. Online kérdőíves felmérés segítségével 383 válaszadót értek el a VEISHEA fesztiválon szerzett élményeikkel kapcsolatban. Vizsgálatuk rá- mutatott arra, hogy mind a négy élménydimenzió pozitívan hat az emlékezetes élmény kialakulására, azonban a lojalitásra csak a szórakozás és az esztétika dimenziója van hatással (MANTHIOU et al. 2014). RIVERA és szerzőtársai (2015) az Aruba szigetén megrendezett zenei fesztivál esetében vizsgálták az Y generációs turisták élményeit, melyhez PINE és GILMORE (1998) élménydimenzióit alkalmazták. Az eredmények azt mutatták, hogy érdemes bevenni a gazdasági érték dimenzióját a vizsgálatba, mellyel megalkották az $5 \mathrm{E}$ modellt a fesztiválokra vonatkozóan. PARK és szerzőtársainak (2010) cikkében egy filmfesztivál résztvevőinek élményét vizsgálták, szintén a $4 \mathrm{E}$ modell alapján, kiemelve azonban a négy dimenzióból az eszképizmus élményét. Tanulmányuk fókuszában az a feltételezés állt, hogy a tanulás, a szórakozás és az esztétikai élmény befolyásolja az elégedettséget és az eszképizmust, mely hatással van a viselkedésre. A cikk eredményei azt mutatták, hogy a $4 \mathrm{E}$ modell elemei nem függetlenek, az eszképizmus élményének kialakulását a másik három elem befolyásolja.

KIM és szerzôtársai (2010) tanulmányukban felmérték a család döntéshozóinak szerepét a fesztiválon való részvételben a fesztiválrészvétel öt szintje alapján: (1. szakasz) mielőtt elmennek a látogatók a fesztivál helyszínére, (2. szakasz) amikor elmennek a fesztiválra, (3. szakasz) amikor ott vannak a fesztivál helyszínén, (4. szakasz) amikor hazamennek, (5. szakasz) a visszatérés. A felmérést két mintavételi csoport felhasználásával végezték: a gyermekes családok és a gyermek nélküli családok. A tanulmány megállapításai között szerepel, hogy a férj leginkább a közlekedéshez kapcsolódó tevékenységekben hoz döntést, beleértve a vezetést, az utazási útvonalak meghatározását, az autóbiztonsági ellenőrzéseket és a tankolást. Ugyancsak kimutatták, hogy a feleség határozott döntéshozó az éttermek vagy menük kiválasztásában, a fesztivál turizmusmenedzsment folyamatában. A feleség szerepe nagyon fontos az első szakasztól az utolsóig, mivel általában ő javasolja a fesztiválon való részvételt és a fesztiválra való visszatérést is. A gyermekek szerepét vagy a közös döntéshozatalt nem vizsgálták (KIM et al. 2010). GRAM (2005) német és dán családokkal készített interjúkkal vizsgálta, és azonosította a gyermekek, a szülók és a család minden tagja számára legjobb élményeket és emlékeket a $4 \mathrm{E}$ modell mentén. Eredményeiben megállapította, hogy míg a szülő́k számára az esztétikai élmények a leginkább emlékezetesek, addig a gyermekek számára sokkal meghatározóbb az eszképizmus, továbbá a közös élményszerzés esetén is az eszképizmus élményelem a legfontosabb. 
A minta demográfiai jellemzői $(n=192)$

\begin{tabular}{|c|c|c|c|}
\hline Változó & $\begin{array}{c}\text { Szent Márton } \\
(41,1 \%)\end{array}$ & $\begin{array}{c}\text { Kürtöskalács } \\
(59,9 \%)\end{array}$ & $\begin{array}{l}\text { Teljes minta } \\
(100 \%)\end{array}$ \\
\hline $\mathrm{Nem}$ & $\begin{array}{l}\text { Férfi: } 26,7 \% \\
\text { Nó: } 73,3 \% \\
\end{array}$ & $\begin{array}{c}\text { Férfi: } 25,9 \% \\
\text { Nó: } 74,1 \% \\
\end{array}$ & $\begin{array}{c}\text { Férfi: } 26,2 \% \\
\text { Nó: } 73,8 \% \\
\end{array}$ \\
\hline Életkor & $\begin{array}{l}\text { Átlag: } 41,3 \\
\text { Szórás: } 11,6\end{array}$ & $\begin{array}{l}\text { Átlag: } 40,4 \\
\text { Szórás: } 10,5\end{array}$ & $\begin{array}{l}\text { Átlag: } 40,7 \\
\text { Szórás: } 10,9\end{array}$ \\
\hline Végzettség & $\begin{array}{c}\text { Diplomás: } 68,1 \% \\
\text { Nem diplomás: } 31,9 \% \\
\end{array}$ & $\begin{array}{c}\text { Diplomás: } 71,3 \% \\
\text { Nem diplomás: } 28,7 \% \\
\end{array}$ & $\begin{array}{c}\text { Diplomás: } 70,1 \% \\
\text { Nem diplomás: } 29,9 \% \\
\end{array}$ \\
\hline Családi állapot & $\begin{array}{c}\text { Házas/Élettársi: } 83,1 \% \\
\text { Egyéb: } 16,9 \%\end{array}$ & $\begin{array}{c}\text { Házas/Élettársi: } 80,2 \% \\
\text { Egyéb: } 19,8 \%\end{array}$ & $\begin{array}{c}\text { Házas/Élettársi: } 81,3 \% \\
\text { Egyéb: } 18,7 \% \\
\end{array}$ \\
\hline Gyermekek száma & $\begin{array}{c}1 \text { gyermek: } 33,3 \% \\
2 \text { gyermek: } 52,2 \% \\
3+\text { gyermek: } 14,5 \%\end{array}$ & $\begin{array}{l}1 \text { gyermek: } 45,0 \% \\
2 \text { gyermek: } 38,7 \% \\
3+\text { gyermek: } 16,2 \%\end{array}$ & $\begin{array}{l}1 \text { gyermek: } 40,6 \% \\
2 \text { gyermek: } 43,9 \% \\
3+\text { gyermek: } 15,6 \%\end{array}$ \\
\hline $\begin{array}{l}\text { Fesztivállátogatás } \\
\text { a családdal évente }\end{array}$ & $\begin{array}{l}\text { Átlag: } 2,75 \\
\text { Szórás: } 1,45\end{array}$ & $\begin{array}{l}\text { Átlag: } 2,73 \\
\text { Szórás: } 1,63\end{array}$ & $\begin{array}{l}\text { Átlag: } 2,73 \\
\text { Szórás: } 1,56\end{array}$ \\
\hline
\end{tabular}

Forrás: saját szerkesztés

\subsection{A CSALÁDBARÁT JELZŐ ÉRTELMEZÉSE A TURISZTIKAI ATTRAKCIÓK ESETÉN}

A családbarát turisztikai szolgáltatások megjelenésére kétféle megoldást találunk a nemzetközi szakirodalomban. Vannak desztinációk, ahol nemzeti szinten határozzák meg, hogy mit jelent a családbarát szolgáltatás, máshol viszont egy alulról jövő kezdeményezésról beszélhetünk, ahol maguk a turisztikai vállalkozások fognak össze és határozzák meg, mit jelent a családbarát jelző használata a turizmusban (HABIBAH et al. 2015). A turisztikai attrakciók közül HALLMAN és BENBOW (2007) kifejezetten az állatkertek esetében vizsgálta, hogy milyen szerepet tudnak betölteni a családok életében, és mennyire tekinthetőek családbarát helynek. Az állatokhoz kapcsolódó kiállítások nagyban előmozdítják a szociális interakciót, és erôsítik a gyermekek és szüleik közötti érzelmi kapcsolatot. A szerzők 140, különbözó családok által készített fotótartalom-elemzéssel végezték vizsgálataikat. Az eredmények két domináns témát azonosítottak a családi fotók alapján: az egyik az állatkert egyes elemeinek megörökítése háttérként a gyermekek vagy család mögött, a másik a családi interakciók ábrázolása, mely rámutat arra, hogy az egész család jól tudja érezni magát az állatkertben. JOHNS és GYIMÓTHY (2002) Dániában készített kutatást családok körében a Legoland, mint témapark, családbarát jellegét fókuszba helyezve. Kutatásukhoz 35 fogyasztói interjút készítettek. Megállapították, hogy a park elsősorban a gyermekek igényeit szolgálja ki. A felnóttek számára sokkal inkább kelt gyermekfelügyelet érzetet az ottlétük, mintsem valódi kikapcsolódást, mely arra világít rá, hogy a családbarát jelzó ebben az esetben a gyermekbarát feltételekkel egyezik meg.

\section{Módszertan}

Jelen tanulmányunkban az alábbi kutatási kérdéseket vizsgáltuk:

- Mekkora az élményértéke a családi fesztiválnak?

- Milyen mérhető összetevői vannak az élménynek?

- Milyen különbségek vannak a két vizsgált fesztivál között az egyes élménydimenziók alapján?

Az adatgyúijtés módja szóbeli kérdőíves megkérdezés volt, amely 2017 őszén, az adott fesztiválok helyszínén, felkészített kérdezóbiztosokkal valósult meg. Az alábbi szúrôkritériumot használtuk: kizárólag a fesztivál helyszínére (saját) gyermekkel érkezó szülóket kérdeztünk. A helyszínek kiválasztása során két, a családokat jelentôs számban elérô, magyarországi fesztivált jelöltünk meg: Szent Márton Újborfesztivál és Libator ${ }^{5}$ (Szentendre, Skanzen), valamint Kürtőskalács Fesztivál ${ }^{6}$ (Gesztenyés Park, Budapest, XII. kerület). Jellemzóen mindkét helyszínre családosok men-

\footnotetext{
${ }^{5}$ A Szent Márton Újborfesztivál és Libatornak a szentendrei Skanzen ad otthont 2004. óta, mely egy kétnapos fesztivál keretében Márton napjához kapcsolódó szokások bemutatásával és családi programokkal színesíti az újbor és liba ételek kóstolását. A rendezvényre többezer ember érkezik évente, mely már Magyar termék Nagydíjat is nyert (Skanzen 2017).

${ }^{6}$ A Kürtőskalács Fesztivált 2013. óta szervezik meg Budapesten, és kb. 1520 ezer látogatója van évente a háromnapos rendezvénynek. Már a második évtől kezdve a Magyar Fejedelmi Pékek Rendjével közösen szervezi a fesztivált a Vitéz Kürtős vállalat, mely 2015-től tagja a Magyar Fesztivál Szövetségnek. A fesztivál célja, hogy a látogatók minőségi, egy egész család számára együtt élvezhető programokon vehessenek részt, miközben hagyományos parázson sült kürtőskalácsot kóstolnak. A programok tárháza igen széleskörü, mely biztosítja az igazi hagyományos családi rendezvényhez szükséges feltételeket (Kürtőskalács Fesztivál 2017).
} 
Lektorált tanulmányok

A tanulmányban bemutatásra kerülő skálák

\begin{tabular}{|l|l|l|l|}
\hline \multicolumn{1}{|c|}{ Fogalom (construct) } & \multicolumn{1}{|c|}{ Skála eredete } & \multicolumn{1}{c|}{ Állitások száma } & \multicolumn{1}{c|}{ Cronbach alfa } \\
\hline Emlékezetes fesztiválélmény & SEMRAD és RIVERA (2016) & 3 állitás & 0,920 \\
\hline Az élmény 5E tényezóje & $\begin{array}{l}\text { SEMRAD és RIVERA (2016) alapján, } \\
\text { módosítva }\end{array}$ & & \\
\hline $\begin{array}{l}\text { Tanulás } \\
\text { (Education) }\end{array}$ & jelentósen módosítva & 5 állitás & 0,925 \\
\hline Szórakozás (Entertainment) & módosítva & 4 állitás & 0,900 \\
\hline Eszképizmus (Escapism) & jelentốsen módosítva & 3 állitás & 0,858 \\
\hline Esztétika (Esthetics) & módosítva & 5állitás & 0,812 \\
\hline $\begin{array}{l}\text { Gazdasági érték (Economic } \\
\text { Value) }\end{array}$ & módosítva & 3 állitás & 0,915 \\
\hline
\end{tabular}

Forrás: saját szerkesztés

nek, de egyik sem úgy pozícionálja magát, hogy családi fesztivál, mivel a családbarát jelzó egyelóre nem definiálható egyértelmúen. Általánosságban nem jellemző Magyarországon ez a típusú pozícionálás, ami egyrészt jövőbeni lehetőség, másrészt felhívja a figyelmet arra, hogy a késóbbiekben ez egy fontos kutatási irány lehet.

Az 1. táblázatból látható, hogy a megkérdezettek demográfiai jellemzói nagyon hasonlóak egymáshoz, nincs szignifikáns eltérés a két alminta között. A kutatásban a 2. táblázatban látható, nemzetközileg is tesztelt skálákat használtuk. A skálákat a kontextusnak megfelelóen adaptáltuk és módosítottuk, a családi fesztiválokra szabtuk. Amennyiben nem létezett az adott fogalom, saját fejlesztésú mérőeszközt használtunk.

A fogalmakhoz tartozó állításokat átlagoltuk (MEAN), a tanulmány további részében ezeket használjuk fel az elemzéshez.

Az élmény öt tényezőjének korrelációs mátrixa

\begin{tabular}{|c|c|c|c|c|c|c|}
\hline & & Tanulás & Szórakozás & Eszképizmus & $\begin{array}{c}\text { Esztétikai } \\
\text { élmény }\end{array}$ & $\begin{array}{c}\text { Gazdasági } \\
\text { érték }\end{array}$ \\
\hline \multirow{3}{*}{ Tanulás } & $\begin{array}{l}\text { Pearson } \\
\text { Correlation }\end{array}$ & 1 &, $572^{* *}$ &, $545^{* *}$ &, $505^{* *}$ &, $388^{* *}$ \\
\hline & Sig. (2-tailed) & &, 000 &, 000 &, 000 &, 000 \\
\hline & $N$ & 192 & 192 & 192 & 192 & 190 \\
\hline \multirow{3}{*}{ Szórakozás } & $\begin{array}{l}\text { Pearson } \\
\text { Correlation }\end{array}$ &, $572^{* *}$ & 1 &, $667^{* *}$ &, $481^{* *}$ &, $353^{* *}$ \\
\hline & Sig. (2-tailed) &, 000 & & , 000 &, 000 & , 000 \\
\hline & $N$ & 192 & 192 & 192 & 192 & 190 \\
\hline \multirow{3}{*}{ Eszképizmus } & $\begin{array}{l}\text { Pearson } \\
\text { Correlation }\end{array}$ &, $545^{* *}$ &, $667^{* *}$ & 1 &, $515^{* *}$ &, $403^{* *}$ \\
\hline & Sig. (2-tailed) &, 000 &, 000 & &, 000 & , 000 \\
\hline & $N$ & 192 & 192 & 192 & 192 & 190 \\
\hline \multirow{3}{*}{ Esztétikai élmény } & $\begin{array}{l}\text { Pearson } \\
\text { Correlation }\end{array}$ &, $505^{* *}$ & $481^{* *}$ &, $515^{* *}$ & 1 &, $391^{* *}$ \\
\hline & Sig. (2-tailed) & ,000 &, 000 &, 000 & &, 000 \\
\hline & $N$ & 192 & 192 & 192 & 192 & 190 \\
\hline \multirow{3}{*}{ Gazdasági érték } & $\begin{array}{l}\text { Pearson } \\
\text { Correlation }\end{array}$ &, $388^{* *}$ &, $353^{* *}$ & $403^{* *}$ &, $391^{* *}$ & 1 \\
\hline & Sig. (2-tailed) &, 000 &, 000 & , 000 &, 000 & \\
\hline & $N$ & 190 & 190 & 190 & 190 & 190 \\
\hline
\end{tabular}

Forrás: saját szerkesztés 


\section{Eredmények}

Az élmény öt dimenziójának korrelációs mátrixából látható (minden kapcsolat szignifikáns), hogy a tanulási élményhez a szórakozás ( $r=0,572)$ és az eszképizmus ( $\mathrm{r}=0,545)$ kapcsolódik a leginkább, a gazdasági érték pedig a legkevésbé $(r=0,388)$. A szórakozással az összes többi tényezố jól korrelál, a leginkább az eszképizmus ( $\mathrm{r}=0,667)$, a legkevésbé a gazdasági érték $(r=0,403)$. Látható, hogy a gazdasági érték dimenziója kicsit kilóg, az korrelál a legkevésbé, bizonyos szakirodalmak emiatt ki is hagyják az elemzésból (3. táblázat). és 4,57) alapján nincs szignifikáns különbség a két fesztivál között, ugyanakkor tanulási (4,82 vs. 3,93) és szórakozási élmény (5,10 vs. 4,73) szempontjából van, mégpedig a Szent Márton Fesztivál javára (4. táblázat).

Másfajta képet kapunk akkor, ha az élménydimenzióknak a fesztivál emlékezetességére gyakorolt hatását vizsgáljuk. Ezt két regressziós modell összehasonlításával tehetjük meg, ahol a függő változó a fesztivál emlékezetessége, a független változók pedig az 5E tényezői. Míg a Szent Márton Fesztiválnál kizárólag a szórakozás gyakorol szignifikáns hatást az emlékezetességre (legalábbis

A két fesztivál összehasonlítása az élménydimenziók (5E) alapján

\begin{tabular}{|c|c|c|c|c|}
\hline Élmény-dimenziók & $\begin{array}{c}\text { Szent Márton } \\
\text { (Szentendre) }\end{array}$ & $\begin{array}{c}\text { Kürtöskalács } \\
\text { (Budapest) }\end{array}$ & Teljes minta & -érték \\
\hline Tanulás & 4,82 & 3,93 & 4,29 & 0,000 \\
\hline Szórakozás & 5,10 & 4,73 & 4,88 & 0,021 \\
\hline Eszképizmus & 4,22 & 4,00 & 4,09 & 0,267 \\
\hline Esztétikai élmény & 4,88 & 4,72 & 4,78 & 0,279 \\
\hline Gazdasági érték & 4,63 & 4,57 & 4,59 & 0,731 \\
\hline
\end{tabular}

Forrás: saját szerkesztés

Megjegyzés: Az élménydimenziók a dimenziót mérő állítások átlagolásával jöttek létre, az állítások értékelése 7 fokozatú Likert skálán történt, ahol 1=egyáltalán nem értek egyet; $7=$ =eljes mértékben egyetértek. Szignifikáns az eltérés, ha p<0,05.

A fesztiválok az élménydimenziók szempontjából közepes (vagy annál kicsit jobb) teljesítményt nyújtanak. Az élmény észlelése természetesen összetett jelenség, amit sokféleképpen lehet befolyásolni, továbbá számos szempont függvénye, ugyanakkor megállapítható, hogy mindkét fesztiválban rejlik még potenciál az élményadás szempontjából. Eszképizmus (4,22 és 4,00), esztétikai élmény $(4,88$ és 4,72), valamint gazdasági érték $(4,63$ ekkora elemszámnál), addig a Kürtőskalácsnál a szórakozás, az eszképizmus, valamint a gazdasági érték is befolyásol. A legerôsebb hatást mindkét esetben a szórakozási élmény gyakorolja (5. táblá$z a t)$.

Ez az eredmény azért érdekes, mert bár a tanulási élmény és az eszképizmus is viszonylag magas értékelést kapott a Szent Márton Fesztiválnál, e tényezők nem gyakorolnak szignifikáns hatást az

5E tényezó hatása a két fesztivál emlékezetességére

\begin{tabular}{|c|c|c|c|c|}
\hline \multirow{2}{*}{5 E tényezök } & \multicolumn{2}{|c|}{ Szent Márton Fesztivál } & \multicolumn{2}{c|}{ Kiurtőskalács Fesztivál } \\
\cline { 2 - 5 } & $\begin{array}{c}\text { Standardizált koefficiens } \\
\text { (Beta) }\end{array}$ & Sig. & $\begin{array}{c}\text { Standardizált } \\
\text { koefficiens (Beta) }\end{array}$ & Sig. \\
\hline Tanulás &, 158 &, 177 &, 013 &, 890 \\
\hline Szórakozás &, 332 &, 005 &, 248 &, 036 \\
\hline Eszképizmus &, 107 &, 341 &, 275 &, 289 \\
\hline Esztétikai élmény &, 186 &, 112 &, 098 &, 004 \\
\hline Gazdaságiérték &, 078 &, 452 &, 239 & \\
\hline
\end{tabular}

Forrás: saját szerkesztés

Megjegyzés: a. Függő változó: a fesztivál emlékezetessége (MEAN); b. Szignifikáns az eltérés, ha p<0,05 
Lektorált tanulmányok

emlékezetességre (legalábbis alacsony mintaelemszámnál). Ez alapján a fesztiváloknak érdemes a szórakoztatási szintet maximalizálni (még családi fesztiválok esetében is), ha emlékezetes élmény átélését szeretnék elérni.

\section{5. Összefoglalás}

Az elméleti részben a turisztikai élmény tisztázását és főbb komponenseinek azonosítását követően a fesztiválokra értelmeztük a négy fogyasztói élménykategóriát: tanulás, esztétika, szórakozás és eszképizmus. A tanulmány újszerúségét az élménydimenziók magyarországi fesztiválokon való tesztelése adja, valamint a kifejezetten családbarát fesztiválokon, családok körében végzett élménykategória elemzés, amely a nemzetközi irodalomban is egyedülálló. A vizsgált fesztiválok az élménydimenziók szempontjából közepes (vagy annál kicsit jobb) teljesítményt nyújtanak, vagyis mindkét fesztiválban rejlik még potenciál az élményadás szempontjából. Eszképizmus, esztétikai élmény, valamint gazdasági érték alapján nincs szignifikáns különbség a két fesztivál között. Tanulási és szórakozási élmény szempontjából a Szent Márton Fesztivál jobban teljesít, melynek maga a helyszín, hogy egy Skanzenban rendezik meg, már erősebb edukációs jelleget biztosít. Ezen túlmenően a személyes élmények megtapasztalásának is nagyobb a lehetősége, ha a tömeg jobban eloszlik egy nagyobb területen. A programok szintén eleve tematizálják a fesztivállátogató családok gondolkodását, hiszen a Szent Márton Fesztivál esetében nagyobb hangsúlyt kapott a tanulási élmény nyújtása. Ezen tényezók feltárása azonban további kutatást igényel.

Ezt a képet árnyalja, hogy míg a Szent Márton Fesztiválnál kizárólag a szórakozás gyakorol szignifikáns hatást az emlékezetességre, addig a Kürtőskalácsnál a szórakozás, az eszképizmus, valamint a gazdasági érték is befolyásol. A legerōsebb hatást mindkét esetben a szórakozási élmény gyakorolja.

Jelen tanulmányban az édesapákat és az édesanyákat nem vizsgáltuk külön-külön, de a késôbbiekben FOUNTAIN és szerzőtársai (2015) alapján érdemes lehet ezt megtenni. Az adatok elemzését klaszteranalízissel folytatjuk a további kutatásokban, mely rávilágíthat arra, hogy a válaszadó szülók milyen családbarát-fesztivál-fogyasztási csoportokba sorolhatóak. A későbbiekben a fesztiválélmények mélyebb feltárása és a két fesztivál közötti különbségek megértése érdekében mélyinterjúkat készítünk a szervezőkkel, továbbá interjúk keretében megkérdezzük a családokat is, ami lehetóséget ad a családbarát fesztiválokon szerezhetó élmények további értelmezésére.

\section{Felhasznált irodalom}

AKYILDIZ, M. - ARGAN, M. (2010): Factors of Leisure Experience: a study of Turkish Festival Participant. Studies in Physical Culture and Tourism. 17(4). pp. 385-389.

ÁSVÁNYI, K. - JÂSZBERÉNYI, M. (2017). The role of rural cities' festivals in the development of regions. DETUROPE - The Central European Journal of Regional Development and Tourism. 9(3). pp. 177-187.

COLE, S. - CHANCELLOR, H. (2009): Examining the festival attributes that impact visitor experience, satisfaction, and re-visit intention. Journal of Vacation Marketing. 15(4). pp. 323-333.

CROMPTON, J. - McKAY, S. (1997): Motives of visitors attending festival events. Annals of Tourism Research. 24(2). pp. 425-439.

FOUNTAIN, J. - SCHANZEL, H. - STEWART, E. - KORNER, N. (2015): Family experiences of visitor attractions in New Zealand: differing opportunities for 'family time' and 'own time'. Annals of Leisure Research. 18(3). pp. 342-325.

GETZ, D. (1997): Event Management and Event Tourism. Cognizant Communications Corporation, New York.

GETZ, D. (2007): Event Studies: Theory, Research and Policy for Planned Events. Taylor \& Francis, Oxford.

GRAM, M. (2005): Family Holidays. A qualitative Analysis of Family Holiday Experiences. Scandinavian Journal of Hospitality and Tourism. 5(1). pp. 2-22.

HABIBAH, A. - HAMZAH, J. - BUANG, A. C. - MUSHRIFAH, I. - SELVADURAI, S. -NOR GHANI, M. N. (2015): An Appraisal of FamilyFriendly Tourism in Malaysia. International Business Management. 9(6). pp. 1523-1534.

HALLMAN, B. C. - BENBOW, M. P. (2007): Family leisure, family photography and zoos exploring the emotional geographies of families. Social and Cultural Geography. 8(6). pp. 871-888.

HUANG, J. Z. - LI, M. - CAI, L. A. (2010): A model of community-based festival image. International Journal of Hospitality Management. 29(2). pp. 254-260.

INKEI P. (2010): A magyarországi fesztiválok minôsitési rendszere. Magyar Fesztivál Regisztrációs és Minősítési Program, Budapest.

JÁSZBERÉNYI M. - ZÁTORI A. - ÁSVÁNYI K. (2017): Fesztiválturizmus. Akadémia Kiadó, Budapest.

JOHNS, N. -GYIMÓTHY,SZ. (2002): Mythologies of a theme park: An icon of modern family life. Journal of Vacation Marketing. 8(4). pp. 320-331. 
KIM, K. - UYSAL, M. - CHEN, J. (2002): Festival visitor motivation from the organizers' point of view. Event Management. 7(2). pp. 127-134.

KIM, S. S. - CHOI, S. - AGRUSA, J. - WANG, K-C. - KIM, Y. (2010): The role of family decision makers in festival tourism. International Journal of Hospitality Management. 29(2). pp. 308-318.

KULCSÁR N. (2015): A fogyasztói érték és az élmény kontextusa a turisztikai szakirodalomban. Vezetéstudomány. 46(3). pp. 18-25.

LEE, C. - LEE, Y. - WICKS, B. (2004): Segmentation of festival motivation by nationality and satisfaction. Tourism Management. 25(1). pp. 61-70.

LEE, Y. - LEE, C. - LEE, S. - BABIN, B. (2008): Festivalscapes and patrons' emotions, satisfaction, and loyalty". Journal of Business Research. 61(1). pp. 56-64.

MANTHIOU, A. - LEE, S. A. - TANG, L. R. CHIANG, L. (2014): The experience economy approach to festival marketing: vivid memory and attendee loyalty. Journal of Services Marketing. 28(1). pp. 22-35.

MEHMETOGLU, M. - ENGEN, M. (2012): Pine and Gilmore's concept of experience economy and its dimensions: an empirical examination in tourism. Journal of Quality Assurance in Hospitality E Tourism. 12(4). pp. 237-255.

MICHALKÓ G. - RÁTZ T. (2005): A kulturális turizmus élménygazdaságtani szempontjai. In: EnyediGy. -KeresztélyK. (szerk.): A magyarvárosok kulturális gazdasága. MTA Társadalomkutató Központ, Budapest. pp. 123-141.

MORGAN, M. (2009): What makes a good festival? Understanding the event experience. Event Management. 12(2). pp. 81-93.

OTTO, J. E. - RITCHIE, J. R. (1996): The service experience in tourism. Tourism Management. 17(3). pp. 165-174.

PARK, M. - OH, H. - PARK, J. (2010): Measuring the experience economy of Film Festival participants. International Journal of Tourism Sciences. 10(2). pp. 35-54.

PINE, B. - GILMORE, J. (1999): The Experience Economy: Work is a Theatre and Every Business a Stage. Harvard, Business School Press. Boston, MA.

PINE, B. J. - GILMORE, J. H. (1998): Welcome to the experience economy. Harvard Business Review. 76(6). pp. 97-105.

PRENTICE, R. - ANDERSEN, V. (2003): Festival as creative destination. Annals of Tourism Research. 30(1). pp. 7-30.

PRENTICE, R. (2004): Tourist motivation and typologies. In: Lew, A. - Ha, M. - Williams, A. (eds): A Companion to Tourism. Blackwell. Oxford. pp. 261-279.
RITCHIE, B. W. - CARR, N. - COOPER, C. (2003): Managing Educational Tourism. Channel View Publications Clevedon.

RIVERA, M. - SEMRAD, K. J. - CROES, R. (2015): The five E's in festival experience in the context of Gen Y: Evidence from a small island destination. Revista Española de Investigación de Marketing ESIC. 19(2). pp. 95-106.

SCHANZEL, H. A. - SMITH, K. A. (2014): The socialization of families away from home: Group dynamics and family functioning on holiday. Leisure Sciences. 36(2). pp. 126-143.

SEMRAD, K. J. - RIVERA, M. (2016): Advancing the 5E's in festival experience for the Gen $Y$ framework in the context of eWOM. Journal of Destination Marketing \& Management. 7. pp. 58-67.

SMITH, M. (2009): Fesztiválok és turizmus: lehetőségek és konfliktusok. Turizmus Bulletin. 13(3). pp. 23-27.

SZABO J. Z. (2012): A turisztikai fesztiválok látogató-összetétele. In: Juhász E. - Chrappán M. (szerk.): Tanulás és mûvelődés. Debreceni Egyetem, Debrecen. pp. 535-540.

TUNG, V. S. - RITCHIE, J. B. (2011): Investigating the memorable experiences of the senior travel market: an examination of the reminiscence bump. Journal of Travel and Tourism Marketing. 28(3). pp. 331-343.

UYSAL, M. - GAHAN, L. - MARTIN, B. (1993): An examination of event motivations: a case study. Festival Management and Event Tourism. 1(1). pp. 5-10.

VAN ZYL, C. - BOTHA, C. (2003): Motivational factors of local residents to attend the Aardklop National Arts Festival. Event Management. 8(4). pp. 213-222.

ZÁTORI A. (2014): Élményszemlélet a turizmusban: A turisztikai élményteremtés koncepciói. Turizmus Bulletin. 16(2). pp. 51-60.

\section{Internetes források}

IPK (2008): European Travel Monitor 2008. IPK International, Munich. https://www.ipkinternational.com/en/world-travel-monitor, Letöltve: 2017. november 20.

KÜRTŐSKALÁCS FESZTIVÁL (2017): Vitéz Kürtôs. http://www.kurtoskalacsfesztival.hu/ vitez-kurtos, Letöltve: 2017. november 20.

MFSZ (MAGYAR FESZTIVÁL SZÖVETSÉG) (2014): Bemutatkozik a Magyar Fesztivál Szövetség. "Szakmai Napok 2014" http://slideplayer.hu/ slide/1929036/, Letöltve: 2017. november 20.

SKANZEN (2017): Szent Márton Újborfesztivál és Libator. http://skanzen.hu/hu/latogatas/programok/programok-2017-ben, Letöltve: 2017. 11.20. 